\title{
Overcoming the "impossible trinity": towards a mix of macroeconomic policy instruments for sustaining economic development in Brazil
}

\author{
ANDRÉ NASSIF*
}

Although there have been more than twelve years since high inflation was eliminated and a floating exchange rate regime was introduced in Brazil in 1999, at least two aspects have clearly marked the Brazilian economy in the 1999-2011 period: first, business cycles were characterised by stop and go behaviour, with annual average growth rates of real GDP $(3.4 \%)$ much lower than the emerging and developing countries $(6.0 \%)$ and very close to the global economy $(3.7 \%$ - see Figure 1$)$; and second, there was a cyclical and persistent tendency of the Brazilian currency to appreciate in real terms (Nassif, Feijó and Araújo, 2011).

As well discussed by many studies ${ }^{1}$, a significant part of this poor performance can be credited, on the one hand, to the Brazilian growth model based on external saving through which growing and unsustainable current account deficits are generally reversed by overshooting of the nominal and real exchange rates and sudden stops. And on the other hand, to a very narrow and orthodox short-term macroeconomic policy which has over-pursued the goals of price stability and monetary independence compared with other equally important economic and social goals, such as a sustainable long-term growth; structural change directed to both diversify exports to sectors of higher technological intensity and prevent the economy

\footnotetext{
* Fluminense Federal University (Universidade Federal Fluminense) and The Brazilian Development Bank (BNDES), Brazil. The opinions expressed in this study are those of the author and do not reflect the views of the Brazilian government and the BNDES. This paper is a modified version of the powerpoint presentation prepared for the Second Workshop on "Financial Stability and Financial Governance in Brazil - Assessing the Landscape and Drawing Policy Implications", Getulio Vargas Foundation (Fundação Getulio Vargas - SP), São Paulo, March 24 and 25, 2011. I thank Carmem Feijó for comments and suggestions. Any remaining errors are the author's responsibility.

${ }^{1}$ See, for instance, Bresser-Pereira and Nakano (2003), Bresser-Pereira and Gala (2008), Nassif (2007), Oreiro et al. (2009) and Bresser-Pereira (2010), among others.
} 
from early deindustrialisation; the improvement of the poor physical and social infrastructure; and so on.

Figure 1: Real GDP growth: Brazil, emerging \& developing countries and world (1999-2011)

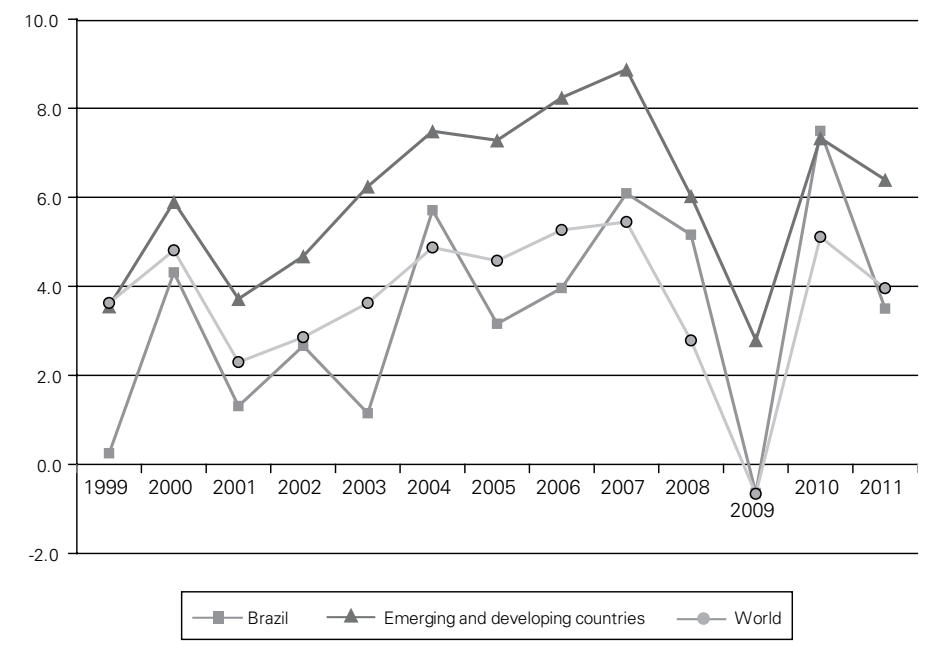

These generally narrow policies were only interrupted during the short period throughout 2009, in response to the recessive impacts of the global economic crisis on the Brazilian economy, and more recently, with the temptation to change the management of the inflation-targeting regime since mid-2011. If whether or not this latter movement will represent a new way of managing the monetary policy in Brazil will be discussed ahead. As Romer (2001, p. 508) recognises, although "inflation targeting is not a policy of focusing only on inflation [...], central banks in inflation-targeting countries appear to place more weight than other central banks on the behaviour of inflation". In Brazil, for instance, the exaggerated weight given to inflation expectations reached a surrealist moment between September and December 2008, when Brazil's Central Bank kept the short-term policy rates unchanged - the Selic rates (at 13.75 per year), notwithstanding the sharp decrease in both commodities and asset world prices, the context of global recession and the strong downturn of Brazilian manufacturing output (for details, see Nassif, 2010).

By being more influenced by the fiscal dominance literature ${ }^{2}$, policy-makers from some emerging countries (Brazil is, perhaps, the major notable case) have taken into account not only the stability of inflation expectations, but also the fis-

\footnotetext{
2 See Sargent and Wallace (1981), Barro and Gordon (1983) and Woodford (2003). For an interpretation of the Brazilian experience in the early 2000s, see Blanchard (2004).
} 
cal equilibrium as sufficient conditions to reduce short-term policy rates. However, as Ocampo (2011, p. 2) argues, rather than "fiscal dominance", the main determinant of the short-term macrodynamics of these countries is "the balance of payments dominance", that is to say, "the regime in which the external shocks, positive and negative, exercises strong procyclical shocks, through the trade account, the availability of external financing, movements in interest rates that have procyclical impacts (increases in risk spreads during booms, reductions during crises), and cyclical effects on exchange rates (appreciation during booms, depreciation during crises) that have more ambiguous effects".

This paper has three main objectives: first, to support the view that, despite recognizing that the policy space for assuring both the internal and external stability is sharply reduced when the "balance of payments dominance" prevails in some open emerging economies like Brazil, even when it is possible to overcome the socalled "impossible trinity", that is, the supposed impossibility of simultaneously guaranteeing the three goals of economic policy in a country with a floating exchange rate regime: price stability, exchange rate stability and (at least, relatively) free capital mobility (second section); second, to argue that not only the pursuance of the exchange rate stability, but also the targeting of the so-called long-term "optimal" real exchange rate - an original concept that was introduced by two other academic colleagues and I (see Nassif, Feijó and Araújo, 2011) and will be defined ahead - should be in the current agenda of the Brazilian policy-makers (third section); and third, the main economic policy implication we can draw from the previous sections are that, instead of a narrow macroeconomic policy as that which prevailed throughout the 2000s in Brazil, policy-makers should urgently mirror most well succeeded Asian countries and adopt a mix of short and long-term economic policy instruments in order to both avoid the "balance of payments dominance" and assure a sustainable long-term economic growth (concluding remarks and policy suggestions).

\section{THE "IMPOSSIBLE TRINITY" IN THEORY AND PRACTISE: ARE POLICY-MAKERS REALLY UNABLE TO OVERCOME ECONOMIC POLICY CONSTRAINTS IMPOSED BY THE “TRILEMMA?}

Since Mundell (1960) pointed out the dilemmas policy-makers have to deal with the choice of a fixed exchange rate and a floating exchange rate regime, the theoretical literature has stressed the trade-offs involved with the advantages and disadvantages of actually adopting one of them. Although the former warrants the stability of the nominal exchange rate, its main cost is associated with the monetary policy's loss of autonomy. In addition, Mundell had clearly emphasized that it would be inconsistent to simultaneously preserve a fixed exchange rate regime and monetary policy independence if policy-makers also opted for free capital mobility. Not by chance, after the set of financial crises in the 1990s (Mexico in 1994; Asian countries in 1997; and Russia in 1998), most governments from emerging countries 
that adopted either a fixed or semifixed exchange rate regime and no capital control, when realizing that this combination left their currencies vulnerable to speculative attacks, immediately replaced that "old" regime for a floating exchange rate regime. Following a strong speculative attack in the end of 1998, Brazil was finally included in these cases with the introduction of a flexible exchange regime in early 1999.

In theoretical terms, however, the adoption of a floating exchange rate regime does not eliminate the dilemmas according to which policy-makers should manage macroeconomic policies following the rule that "for each goal might correspond only one macroeconomic policy instrument". This means that even a floating exchange rate regime does not release policy-makers from facing the "trilemma" of economic policy according to which they may only choose two out of the three economic policy goals: monetary independence, exchange rate stability and external financial integration. Taking Brazil as a paradigm, we could state that, in the last twelve years, policy-makers' choices have rested upon price stability and free capital mobility, in detriment of exchange rate stability ${ }^{3}$. These choices are clearly in tune with the rule according to which each goal is consistent with only one economic policy instrument. Then, by applying the "impossible trinity" to the Brazilian case, we could state that while the independence of monetary policy within an inflation targeting framework might guarantee price stability, the freedom for capital flows would act as a coadjuvant mechanism for the balance of payments (BoP) adjustments. In accordance with the predictions of the Mundell-Fleming model, Brazilian policy-makers have believed in the role of the flexibility of the exchange rates as the main mechanism that provides the BoP adjustments.

In practise, however, there are three issues that could put in doubt the ability of a floating exchange rate regime to efficiently work as an autonomous mechanism for promoting the adjustment of the BoP in a soft and automatic way and independently of the monetary policy. First, as stressed by Mundell (1960), since the internal consistency of a model with a floating exchange rate and capital mobility depends on the manipulation of the interest rate, this latter instrument affects the stability of domestic prices in an indirect way. The change in the interest rate aimed at controlling aggregate demand affects, first, the short-term capital flow, which in turn affects, albeit with some time lag, the exchange rate which in turn again is adjusted to restore the equilibrium in the market of goods and services as well as the balance of payments. In this way, in economies that are open to free capital movements, the transmission mechanism of the monetary policy operates through the exchange rate. This occurs because the sensitivity of the adjustment in the market of goods and services is inferior to the sensitivity of the changes in the capital movements to the interest rate.

Second, in open emerging economies, the celebrated uncovered interest rate par-

\footnotetext{
${ }^{3}$ As will be discussed ahead, these choices have softly changed in 2010 , when some ad hoc measures of capital control were introduced.
} 
ity hypothesis is recurrently violated as an efficient mechanism to explain not only the relationship between the short-term interest rates differential and the expectations of depreciations of their currencies (given the country-risk premium), but also the stability of both capital flows and, therefore, the nominal (and real) exchange rate. In fact, the uncovered interest rate parity $\left(i=i^{*}+e^{e}+C R\right)$ determines that the domestic interest rate, $i$, is equal to the international rate, $i^{*}$, plus the expectation of depreciation of domestic currency, $e^{e}$ and the country-risk premium $C R^{4}$.

For instance, if the country-risk premium increases, the domestic currency is expected to depreciate $\left(e^{e}>0\right)$. If a high instability in the foreign exchange market is observed, the threat of depreciation puts pressure on the domestic interest rate to keep domestic assets attractive. This suggests a positive correlation between the short-term interest rate differential and the nominal (and real) exchange rate in the very short-term.

However, as soon as the foreign exchange market is stabilized again, an appreciation of the exchange rate is expected in response to the manipulation of the domestic interest rate by the central bank to avoid currency depreciation. The systematic increase in the short-term interest rate differential represents an additional incentive to sustain the exceeding flows of foreign short-term capital, especially that of a speculative nature. In practical terms, since foreign investors tend to bet on the appreciation trend of currencies in emerging economies in the near future, the use of these currencies for carry-trade strategies implies that the uncovered interest rate parity is explicitly violated in the short term. In fact, instead of reflecting expectations of depreciation, the higher the interest rate differential, the greater the expectation is that the domestic currency will continue to appreciate. So, in this case, the effect of an increase in the interest rate differential on exchange rate appreciation occurs with some time lag due to the attractiveness of large shortterm capital inflows. This tendency will only be interrupted by sudden stops. In other words, this suggests that, in practise, not only the exchange rates in open emerging economies are far from being characterised by low volatility, but also the flexibility of their exchange markets does not provide them soft adjustments of the BoP.

Third, when international liquidity is plentiful and enhanced by large global current account imbalances - as has been the case in the world economy since the mid-2000s —, net foreign capital inflows are pushed towards open emerging economies in amounts much larger than the need of preserving the BoP equilibrium. This situation means that, in practise, the supposed independence between both the exchange rate behaviour and monetary policies, as suggested by the MundellFleming model, is a mere fiction. Actually, in these cases, central bankers have to

\footnotetext{
${ }^{4}$ Consistent with the uncovered interest rate hypothesis, this would suggest a positive correlation between either expectations of exchange rate depreciation or the augment of the country-risk premium and an increase in the domestic interest rate, in the assumption that the international interest rate remains unchanged.
} 
deal with the dilemmas imposed by such a straitjacket. If they choose to keep the exchange rates freely floating, the domestic currency will tendencially appreciate and accumulate a large level of overvaluation. In order to avoid this latter trend, monetary authorities are compelled to purchase large amounts of international reserves. The issue is that, when there is a lack of adequate sterilization of the monetary impacts of the previous policy, the overaccumulation of international reserves provided by large external savings might generates bubbles in asset prices and credit. Consequently, policy-makers face a trade-off between purchasing international reserves to avoid a large real overvaluation of domestic currency and, since they have to sterilize the monetary impacts of that policy, absorbing this extra burden on gross public debt. This means that, in practise, monetary policy goes beyond the announced goal of keeping the inflation controlled, especially in countries like Brazil, which manage the monetary policy in an inflation targeting framework.

This Section must now give an answer for part of its title: are policy-makers really unable to overcome economic policy constraints imposed by the "trilemma? Based on the arrangements of macroeconomic policies in most Asian countries, we could anticipate a "no." Aizenman et al. (2010) showed sound econometric evidence that, since the Asian crisis of 1997, most Asian countries (except China), even without giving up a floating exchange rate regime and freedom of capital movements, have been very successful in by-passing the "impossible trinity" through an aggressive policy of accumulation of international reserves. So, at least in in middle-term, policy-makers are able to overcome the constraints imposed by the impossible trinity", in other words, rather than a dirty floating exchange rate regime like most Lain American countries (including Brazil), the Asian countries have, in practical terms, an administered floating exchange rate regime. India, for stance, has a large and growing exchange market that operates under a floating exchange regime. However, Reserve Bank of India intervenes as much as possible by purchasing international reserves. At the same time, as it also has a large gross public debt as a proportion of GDP - with the advantage that most of the stock of Treasury issued bonus are of long-term maturity —, its policy-makers combine other instruments favourable to either avoid overvaluation or even promote small undervaluation (Nassif, 2007). One of these instruments is to stimulate Indian companies to purchase foreign assets (especially through equities and foreign direct investment - FDI $)^{5}$.

Summing up, we could state that such strategies that combine a mix of macroeconomic policies to keep low nominal and real short-term interest rates as well as a small real exchange rates undervaluation - the main macroeconomic prices that, ceteris paribus, are able to sustain growth in the long-term (see Rodrik, 2008;

\footnotetext{
${ }^{5}$ Beena (2011, p. 22) showed empirical evidence of "an increasing trend of Indian firms purchasing firms or assets abroad during 2000 to 2010" and stressed that in the 2007-2008 fiscal year, Indian FDI outflows already surpassed Indian FDI inflows.
} 
Williamson, 2008; and Berg and Miao (2010) - could be named "the Asian growth model" for they are able to put their economies in the successful trajectory of economic development. The strategy followed by Brazil from 1999 to 2011 and some Latin-American countries could be named "the peripherical growth model" for, by combining a high short-term interest rates differential and a real exchange rate overvaluation trend, they have submitted their economies to low rates of labour productivity growth, stop and go growth behaviour and a trajectory of fallingbehind in the long-term ${ }^{6}$.

\section{MAKING LIKE THE ASIAN COUNTRIES: TOWARDS A TARGET TO REACH THE LONG-TERM “OPTIMAL” REAL EXCHANGE RATE FOR ASSURING ECONOMIC DEVELOPMENT IN BRAZIL}

Economic development is a complex phenomenon which depends on economic factors, especially the augmenting of the capital stock and technological progress, but that is also influenced by other non-economic causes, such as historical, geographical, sociological, political and even cultural ones. However, from the 1990s on, there has been a vast empirical literature which has provided sound evidence that, considering everything equal, the exchange rate overvaluation has negative effects on long-term economic growth (Razin and Collins, 1999; Dollar and Kraay, 2003; Prasad, Rajan and Subramanian, 2006; Gala, 2008). Rodrik (2008) and Berg and Miao (2010) went further and showed empirical evidence that not only does overvaluation damage growth, but also that undervaluation benefits growth. Also, Williamson (2008) suggests that "the very best policy (in terms of maximizing growth) appears to be a small undervaluation" (p. 14, italics from the original).

Inspired in this latter evidence and recognizing the special role of the real exchange rate for sustaining economic development, two academic colleagues and I (Nassif, Feijó and Araújo, 2011) introduced the concept of the long-term "optimal" real exchange rate. It means a "long-term reference real exchange rate which is able to reallocate the productive resources towards the sectors with the highest productivity and, considering everything else equal, directs the economy as a whole towards technological and economic catching-up in the long run" (Nassif, Feijó and Araújo 2011: 5). Coherently with the above mentioned empirical literature on the relationship between the real exchange rate and economic development (Rodrik,

\footnotetext{
${ }^{6}$ See Cimoli, Porcile and Rovira (2009) for the Latin-American case. Although the authors do not assure that Brazil has clearly fallen behind in the 1960-2004 period, as a matter of fact, their empirical evidence showed that Brazil can be surely included in the group that failed to converge to developed countries' technological and income per-capita patterns. In virtue of the low average investment rates as proportion of GDP in Brazil - one of the main causes of this fail for the Latin-American case as whole, according to the authors - from 2004 on, the long-term performance in Brazil has hardly shown significant change.
} 
2008; Williamson, 2008; Berg and Miao, 2010), this "optimal" rate must incorporate a small undervaluation ${ }^{7}$.

In our paper, we developed a theoretical and empirical model that allowed us not only to show the main determinants of the long-term trend of real exchange rate in Brazil (and its persistent trend of overvaluation) in the period February 1999-February 2011, but also to estimate the long-term "optimal” real exchange rate that should have been set in motion in April 2011 for putting the Brazilian economy in a sustainable growth trajectory. Among all explanatory variables incorporated into our econometric model, the GDP per-capita, the terms of trade and the short-term interest rates differential not only were significant, but also showed the largest coefficients, respectively, for explaining the long-term trend of RER in Brazil during the estimated period. Our study also revealed another important result: in April 2001, the Brazilian real showed a real overvaluation of around $82 \%$ in relation to the long-term "optimal" real exchange rate, estimated at 2.90 Brazilian reals per dollar (against an observed nominal exchange rate of 1.59 Brazilian reals per dollar $)^{8}$.

Although we ourselves were, at first sight, surprised with so large an estimated level of overvaluation - most observed calculations of the level of misalignment based on relative purchasing power parity indicated levels of overvaluation for the Brazilian currency of around 30\% related to the US dollar in April 2011 (supposing the average real exchange rate of 2000 as equal to 100) - , at least three reasons suggest our estimations were sound: first, when the nominal exchange rates are characterised by high level of volatility like in Brazil, calculations based on only relative PPP are not sufficient for giving an adequate reference rate for the real exchange rate; second, despite applying a different methodology, Goldman Sachs (Apud Lamucci, 2011) estimated the real exchange rate in Brazil, adjusting the changes in nominal exchange rates by variables such as domestic and international price indices, GDP per-capita and the terms of trade, and concluded that in July 2011 the Brazilian real was approximately $73 \%$ overvalued in relation to the US dollar, a result not very far from ours ${ }^{9}$; and third, as Figure 2 confirms, by comparing with the actual behaviour of the RER, the estimated trends of the longterm trend of the RER were very close to each other in all applied econometric regressions (ordinary least squares - OLS, two stages least squares - 2SLS and error correction model - ECM).

\footnotetext{
${ }^{7}$ Since this reference rate is not linked to any maximization function, nor a neutral equilibrium real exchange rate (as in the purchasing power parity hypothesis - PPP), the term "optimal" must always be written between brackets and is completely in tune with the Structuralist literature on economic development and some of its main authors, such as Raúl Prebisch, Nicholas Kaldor and A.P. Thirlwall.

${ }^{8}$ All details of the theoretical and empirical model can be found in Nassif, Feijó and Araújo (2011).

${ }^{9}$ Note that our "optimal" real exchange rate, by incorporating a small level of undervaluation, is not a neutral equilibrium exchange rate à la PPP.
} 
Figure 2: Actual and long-term estimated real exchange rates in Brazil:

February 1999-February 2011 (in logarithms)

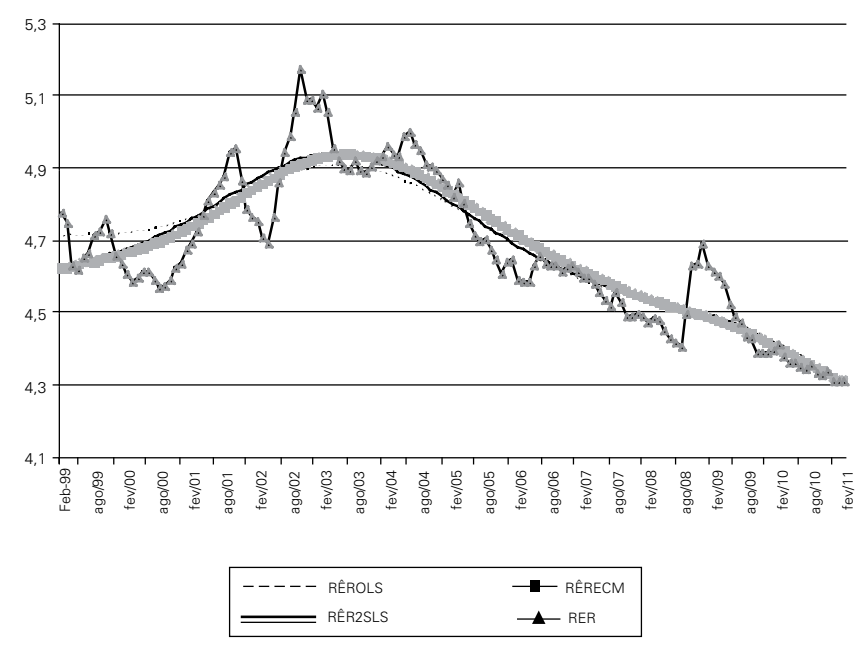

Source: Nassif, Feijó and Araújo (2011).

As Figure 2 confirms, since a floating exchange rate regime was introduced in Brazil in early 1999, there has been a persistent trend of real overvaluation of domestic currency which was only broken by sudden internal or external shocks, such as those of 2001 (due to a serious electric energy crisis — the apagão crisis), 2002 (due to negative expectations of the election of Luiz Inácio Lula da Silva, then evaluated as a radical leftist by markets) and in the aftermath of the September 2008 global financial crisis. The major challenge Brazilian policy-makers are faced with in the coming years is to think about how to replace the old model, in which growing current account deficits are financed by large and unsustainable net foreign capital inflows (especially short-term ones), by a new one based on a mix of macroeconomic policy instruments which are able to correct the two anomalies of the Brazilian economy in the current days - high real interest rates and large overvaluation of the domestic currency. This agenda should include a targeting for reaching the long-term "optimal" real exchange rate. The issue is whether or not it is possible to find an organised exit for such adjustments when the level of overvaluation has reached a significant magnitude as has happened in the case of Brazil.

\section{CONCLUDING REMARKS AND POLICY SUGGESTIONS: TOWARDS A MIX OF MACROECONOMIC POLICY INSTRUMENTS FOR SUSTAINING ECONOMIC DEVELOPMENT IN BRAZIL}

Nowadays, there is some consensus that the main causes of the Asian crisis in 1997 were linked to the rapid process of external financial openness, which was responsible for large net capital inflows, high level of domestic currency overvaluation and bubbles in the asset prices (see Krugman, 1998; and Stiglitz, 2002). As 
Aizenman et al. (2010) showed, since then, Asian governments, even though not having given up completely to the combination of a floating exchange rate, the liberalization of the capital account and the relative independence of monetary policy, have actively intervened in the exchange markets by purchasing and accumulating a massive stock of international reserves ${ }^{10}$. The main purpose of these administrated floating exchange rate regimes is to prevent Asian domestic currencies from the overvaluation trend. In addition, in practise, by coordinating monetary and exchange rate policies, Asian policy-makers implicitly target a small level of real undervaluation of their currencies, aiming at preserving the level of competitiveness of their economies and avoiding balance of payments crises. In short, Aizenman et al. (2010) suggest that, since Asian governments do not guide their macroeconomic policy strictly in accordance with the predictions of a pure Mundell-Fleming model as described in most international economics textbooks, they were able to learn from their past mistakes.

By comparing with Brazil, we could not draw the same previous conclusion. After the introduction of the floating exchange rate regime in 1999, Brazil suffered from the violent aftermaths that followed the three episodes of strong depreciation of its currency (in 2001, 2002 and 2008) and, even so, policy-makers did not take care to avoid new tendencies of real exchange rate overvaluation. The main reason is linked to the lack of coordination between both lato sensu long-term economic policies and strictu sensu monetary, fiscal and exchange rate policies. With a real overvaluation of around $82 \%$ in relation to the long-term "optimal" exchange rate, it is neither recommended to introduce measures to correct so large a misalignment nor would it be possible to do so without strong macroeconomic disequilibrium. This means that, taking into account that as the ad hoc correct measures of capital control were ineffective to deter the trend of overvaluation, sooner or later this large misalignment of the Brazilian real might be violently adjusted by market forces in the short coming years, independently of whether or not the scenario in the world economy will be charaterised by a new strong downturn ${ }^{11}$. Subsequently, I will briefly propose and discuss some suggestions of a mix of economic policies - that is to say, a set of long and short-term economic policy instruments in which coordination is the key condition for their effectiveness - directed to sustain economic development in Brazil and having as an assumption that the departure should be from a new neutral equilibrium real exchange rate that might follow the above mentioned strong depreciation ${ }^{12}$.

\footnotetext{
${ }^{10}$ This does not mean, however, that either the floating exchange rate regime is completely free or the capital account is fully convertible. As to monetary policy, relative independence means that the use of its instruments is, in principle, independent of the exchange rate policy, but a coordination between both policies is used whenever it is necessary.

${ }^{11}$ This same position was manifested by professor Francisco Lopes (2011) for whom "the speculative bubble associated with the accumulation of international reserves is willing to blow between 2012 and 2015".

12 This does not mean that Brazil's Central Bank should passively accept the continuation of the overvaluation trend of the Brazilian real. This point will be briefly discussed ahead.
} 
i) Industrial, technological and other long-term policies: Since 2004, with the implementation of the Foreign Trade, Technological and Industrial Policy (Politica Industrial, Tecnológica e de Comércio Exterior - PITCE) $)^{13}$, much effort has been made in Brazil to induce reallocation of resources towards sectors of high productivity and major technological intensity. Much more complex and ambitious, subsequently, was the Policy of Productive Development (Política de Desenvolvimento Produtivo - PDP $)^{14}$, raised in 2009 , for the main goals were to boost the innovation and technological progress as well as to induce large investments in physical infrastructure in Brazil. As shown by the empirical evidence, since one of the longterm structural explanations for the overvaluation trend of the Brazilian real has been the favourable terms of trade, due the high export concentration in primary products, food and other industrialized commodities, industrial and technological policies of those kind are fundamental to avoid early deindustrialization as well as to induce structural change and economic development. However, entrepreneurs will judge high the opportunity costs associated with physical investment and research and development $(\mathrm{R} \& \mathrm{D})$ when the real interest rates are too high compared with the world economy and the trend of the real exchange rate is persistently overvalued as it has been in Brazil in the last decade. This is the reason why the maximization of the performance of the industrial and technological policies depends on a fine and continuous coordination with other economic institutions, especially those dealing with the monetary, fiscal and exchange rate policy ${ }^{15}$.

Another suggestion related to the long-term policies is that Brazil should mirror India's strategy in the past few years of aggressively inducing the internationalisation of their national enterprises (see Nassif, 2007). Far from being a policy to export domestic employment, as one could simplistically criticise, the strategy of creating and boosting Brazilian multinationals could provide two main benefits: first, it could contribute to augmenting the economies of scales of the Brazilian enterprises and accelerating their technological learning; and second, by increasing the domestic demand for long-term foreign assets - especially through foreign direct investment (FDI) - it could also push the demand of dollars up in the Brazilian spot exchange market and, furthermore, help to gradually depreciate the Brazilian real, considering everything else equal. In other words, the strategy of boosting the internationalisation of the Brazilian enterprises could both work as industrial and exchange rate policies.

ii) Monetary policy: It is not intended here to question a monetary policy based on an inflation targeting regime framework per se, but the conservative way with which Brazil's Central Bank has managed the regime, especially the short-term policy rates, at least until mid-2011. There is no room in this paper to detail the specificities of the management of the policy rates (the primary short-term interest rate Selic), but it is enough to remember once again that the Brazilian Monetary

\footnotetext{
${ }^{13}$ See MDIC (2003).

${ }^{14}$ See MDIC (2009).

${ }^{15}$ For a comparison between Brazil and India, see Nassif (2007).
} 
Committee of Brazil's Central Bank, differently from most central banks in the world, kept unchanged the Selic at $13.75 \%$ per year between September 2008 and December 2008, despite the sharp drop of commodity prices and strong downturn in the Brazilian monthly manufacturing production. Once Brazilian monetary authorities were worried about the augmenting of inflation expectations in a context of an effective drop in world prices, this decision had to be evaluated as a serious macroeconomic policy mistake.

In addition, as Lopes (2011) pointed out, although Brazil' s Central Bank has lately reduced the Selic rate from $13.75 \%$ p.y in January 2009 to 8.75 p.y. in June 2009, "as the U.S. Federal Reserve Bank went around in the same direction, this decision was very timid and inferior to the reduction of the U.S. policy rate between mid-2007 and the end of 2008". In other words, notwithstanding the context of the global economic crises, the short-term interest rates differential has increased in Brazil. It is curious that part of the Brazilian press used to refer to the governor of Brazil's Central Bank, Henrique Meirelles, between 2003 and 2010 as "the guardian of the financial stability" of the eight years of the president Luiz Inácio Lula da Silva (see Veja, 2010). This exaggerated evaluation has been reconsidered by recent empirical evidence. Luporini (2010: 2), for instance, presents sound econometric evidence that "from 1991 through 2009 the analysis indicates that domestically, the nominal interest rate has been the major source of macroeconomic instability while the exchange rate market has been the main channel through which international shocks have affected the Brazilian economy" ${ }^{16}$.

It is needed to recognise that, since mid-2011, the new Monetary Committee of Brazil's Central Bank, under governor Alexandre Tombini, has essayed to implicitly change the conduction of monetary policy in Brazil. At least three new aspects can be noticed: first, a better coordination between monetary authorities and other economic ministries, especially the Ministry of Finance; second, the use of other mechanisms of monetary control (e.g., the requirement of compulsory reserves and macroprudential measures, among others) as complements of the basic policy rates; and third, for the first time since the introduction of the inflation targeting in Brazil, it seems that the monetary authorities are trying to manage the regime focusing not only on inflation but also on the actual and expected behaviour of the real economy. It is early, however, to predict whether or not the decisions of the Brazilian Monetary Committee in the coming years will be taken more independently of the pressures of financial markets and will follow the Romer (2001) observation that "central banks in inflation-targeting countries, like other central banks, do not just try to control inflation; they also try to mitigate output fluctuations, avoid large swings in interest rates and exchange rates, and keep the financial system stable".

At least, the first aspect deserves an additional comment. It is misleading to interpret the coordination between monetary, fiscal and exchange rates policies as a way of reducing the de facto operational independence of Brazil's Central Bank.

\footnotetext{
${ }^{16}$ Needless to say that, since the empirical research covered a large period from 1991 on, the same conclusion must be extended to the monetary policy implemented in the presidencies of Fernando Collor de Mello, Itamar Franco, Fernando Henrique Cardoso and Luiz Inácio Lula da Silva.
} 
In practice, central banks coordinate those policies, even when they are de jure independent. For instance, the U.S. Federal Reserve Bank (FED), which is de jure independent, since 2008 has shown fine coordination with the U.S. Treasury with the implementation of the so-called quantitative easing $(\mathrm{QE})$ through which the FED has unconventionally purchased U.S. Treasury Notes of medium and longterm maturity aiming at pushing down the Notes' yields as well as US interest rates across debt markets that are closely tied to U.S. Treasury rates (The Wall Street Journal, 2010). In other words, through such coordination, the FED is trying desperately to induce the recover of the U.S. economy. Yet in India, where its central bank is not de jure independent, coordination of monetary, fiscal and exchange rate policies is a normal practice (see Nassif, 2007).

Another important suggestion for the improvement of the inflation targeting regime in Brazil is that, given the extreme difficulty in conciliating the reduction of the still high nominal interest rates in Brazil to bring the actual inflation to the centre of the targeting in a calendar year, the inflation target could be managed through an augmenting "year" of 18 months (see, among others, Oreiro et al., 2009; and Squeff et al., 2009). Far from a misleading interpretation of accepting a little more inflation in benefit of a more real GDP growth, by giving monetary authorities more room to reduce the Selic basic interest rates, this change could help to adjust the misalignment in the real exchange rate in Brazil.

iii) Fiscal policy: The Brazilian debate on the relationship between fiscal policy and real exchange rates behaviour opposes two theoretical positions: the first one assumes that the relatively low level of private and governmental savings is the main factor to explain the persistence of the real overvaluation of the domestic currency. Based on the accountable interrelationships between excess of investment over total domestic savings and current account deficits, these latter are explained by the shortage of domestic savings. In other words, for this group, the trend of real overvaluation of the domestic currency is the consequence, not the cause of growing current account deficits (see, for instance, Pastore and Pinotti, 2011); the second one, assumes that, although there is an unquestionable accountable ex-post relationship between the excess of investment over total domestic savings and current account deficits, these latter are basically explained by the real overvaluation of domestic currency. For this group, a currency overvalued, not only contributes to low rates of labour productivity, but also tends to augment the domestic wages when expressed in dollar terms. This tends, in turn, to sharply increase the domestic consumption (and considering everything equal, to reduce total domestic savings) through import booms (see, for instance, Bresser-Pereira and Gala, 2008; and Bresser-Pereira, 2010).

For being shared with the second position, I support the view that the fiscal responsibility through a tight control of superfluous current government expenditures can be an important allied mechanism for both giving Brazil's Central Bank more room to reduce short-term interest rates and liberalising resources to augment the public investment in Brazil. However, the fiscal adjustment per se is not a sufficient condition for reducing high interest rates in Brazil. In addition, as the shortterm policy rates in Brazil (the Selic rate) are both used for controlling aggregate demand in the inflation targeting regime and for yielding the short-term Brazilian 
Treasury Bonds (the LFTs), a procyclical fiscal policy can become ineffective in the long-term for Brazil's Central Bank is obliged to increase the Selic rate everytime policy-makers face a internal or external shock ${ }^{17}$.

iv) Exchange rate policy: Compared with Asian countries, Brazil's Central Bank has a much more reduced policy space for helping to keep the domestic currency at a small level of real undervaluation through a massive accumulation of reserves. The main constraint is linked to both the (still) high short-term interest rates and the short duration of the total gross public debt. One could argue that, even so, Brazil has, paradoxically, accumulated a large amount of international reserves. However, regarding this issue, two points must be stressed here: first, notwithstanding that the stock of international reserves has increased from US $\$ 83$ billion in November 2006 to US $\$ 352$ billion in November 2011, differently from Asian countries, this dramatic increase was not sufficient to avoid the sharp trend of overvaluation of the Brazilian real; second, while between 2006 and 2007 the increase in the international reserves was associated with a current account surplus, the additional augmenting of US\$195 billion in the total stock of the Brazilian international reserves until November 2011 was associated with large net capital inflows. This is the reason why Lopes (2011) named this strategy as "a speculative accumulation of international reserves".

In this respect, despite recognising the high opportunity costs associated with the accumulation of reserves in Brazil, I support the view that, since this strategy helps to contain the trend of overvaluation, Brazil's Central Bank should continue to pursue it. However, this strategy should be submitted to the continuous management of the impact of purchasing additional international reserves in the spot foreign exchange market on the growth of the Brazilian gross public debt.

v) Capital controls: I also support the view that policy-makers should not discard new measures of capital controls, in addition to the ad hoc measures that have already been implemented since mid-2010. Even though capital controls are not a panacea, even conservative voices have upheld that some sort of protection against speculative short-term capital inflows should be established by emerging economies to avoid exchange rate overvaluation. A recent International Monetary Fund Staff Position Note (see Ostry et al., 2010, p. 15, among others) concluded that "capital controls are a legitimate part of the toolkit to manage capital inflows in certain circumstances".

The main issue is that these governmental measures (including the mix of the above suggested macroeconomic policies) should have been implemented in mid2009 , when the real exchange rate began to show a sustained trend of appreciation and not in ad hoc small doses as has occurred from early 2010 on. Currently (October 2011), as the current account deficits have increased dramatically from 2008 to 2011, the imposition of radical measures of capital control (e.g., quantitative constraints against capital inflows) is much harder to implement, given the need of large amounts of external savings to finance the current account deficits. In other words, it is much more difficult to find an organized exit from a potential

${ }^{17}$ For a similar critique, see Ocampo (2011). 
exchange rate crisis when the country's external financial vulnerability has dramatically increased ${ }^{18}$.

\section{REFERENCES}

AIZENMAN, J., CHINN, M. D., and ITO, H. (2010). "Surfing the Waves of Globalization: Asia and Financial Globalization in the Context of the Trilemma". La Follette Working Papers Series 2010009. Robert M. La Follette School of Public Affairs. The University of Wisconsin-Madison.

BARRO, R. and GORDON, D. (1983). "Rules, Discretion and Reputation in a Model of Monetary Policy", Journal of Monetary Economics, 12, 101-121.

BEENA, P. L. (2011). "Financing pattern Indian corporate sector under liberalisation: With focus on acquiring firms abroad". Working Paper 440. Trivandrum, Kerala, India: Centre for Development Studies (available at http:www.cds.edu).

BERG, A. and MIAO, Y. (2010). "The real exchange rate and growth revisited: The Washington Consensus strikes back?” IMF Working Paper 10/58. Washington: International Monetary Fund.

BLANCHARD, O. (2004). "Fiscal dominance and inflation targeting regime: Lessons from Brazil". NBER Working Paper Series nr 10389. Cambridge, MA: National Bureau of Economic Research, March.

BRESSER-PEREIRA, L. C. (2010). Globalization and competition. why some emerging countries succeed while others fall behind. Cambridge: Cambridge University Press.

BRESSER-PEREIRA, L. C. and GALA, P. (2008). "Foreign savings insuffiency of demand, and low growth". Journal of Post-Keynesian Economics, vol. 30, $\mathrm{n}^{\circ} 3$. April.

BRESSER-PEREIRA, L. C. and NAKANO, Y. (2003). "Crescimento econômico com poupança externa?” Brazilian Journal of Political Economy, 23 (2). (available at http://www.rep.org.br).

CIMOLI, M., PORCILE, G. and ROVIRA, S. (2009). "Structural change and the BOP-constraint: Why did Latin America fail to converge?" Cambridge Journal of Economics 34: 389-411.

DOLLAR, D. and KRAAY, A. (2003). "Institutions, trade and growth". Journal of Monetary Economics. Elsevier, vol. 50, $\mathrm{n}^{\circ}$ 1:133-162. January.

GALA, P. (2008). "Real exchange rate levels and economic development: Theoretical analysis and econometric evidence". Cambridge Journal of Economics 32:273-288.

KRUGMAN, P. (1998). “What Happened to Asia?” Cambridge (MA): Department of Economics, Massachusetts Institute of Technology (MIT). Availabe at the website http://www.mit.edu/krugman.

LAMUCCI, S. (2011). “A indústria perde competitividade”. Valor Econômico, July 8, 2011.

LOPES, Francisco (2011). "Sobre risco cambial, besouros e borboletas". Valor Econômico, June 15, 2011.

LUPORINI, V. (2010). "Macroeconomic volatility and policy response: The case of Brazil”. Documento de Trabajo. Taller "Volatilidad Macro y Espacio Fiscal", 3 y 4 de agosto de 2010. Santiago de Chile: Comisión Econômica para América Latina y el Caribe (available at http://www.eclac.cl/de/ agenda/1/40121/Luporini_Brasil_Final_abril_2010.pdf).

MDIC (2003). Diretrizes de Política Industrial, Tecnológica e de Comércio Exterior. Brasília: Ministério do Desenvolvimento, Indústria e Comércio Exterior (available at http://www.mdic.gov.br).

MDIC (2009). "Inovar e investir para sustentar o crescimento”. Brasília: Ministério do Desenvolvimento, Indústria e Comércio Exterior”. October 9, 2009 (available at http://www.mdic.gov.br/pdp/).

\footnotetext{
${ }^{18}$ According to Brazil's Central Bank database (http://www.bcb.gov.br), between 2006 and 2007 the current account surplus in Brazil was reduced from US $\$ 13,6$ million to US\$1,6 million $(1.2 \%$ and $0.1 \%$ of GDP, respectively). Between 2008 and 2010, the current account deficits have increased from -US $\$ 28,2$ million (1.7\% of GDP) to -US\$47,4 million (2.3\% of GDP). In October, 2011 the current account deficit was around US $\$ 47,3$ million in a yearly basis (or $2 \%$ of GDP). Although Brazil's Central Bank statistics account for large amounts of foreign direct investment, most of these have been related to intrafirm lendings.
} 
MUNDELL, R. A. (1960). "The monetary dynamics of international adjustment under fixed and flexible rates", Quarterly Journal of Economics, vol. 74, $\mathrm{n}^{\circ}$. 2: 227-57.

NASSIF, A. (2007). "National innovation system and macroeconomic policies: Brazil and India in comparative perspective", UNCTAD Discussion Papers no 184. Geneva: United Nations Conference on Trade and Development, May (available at http://www.unctad.org).

NASSIF, A. (2010). "Brazil and India in the global economic crisis: Immediate impacts and economic policy responses” In: S. Dullien, D. Kotte, A. Márquez and J. Priewe (eds). The Financial and Economic Crisis of 2008-2009 and Developing Countries. Jointly published by the United Nations Conference on Trade and Development and Hochschule für Technik und Wirtschaft Berlin (available at https://www,unctad.org/ UNCTAD/GDS/MDP/2010/1 - E.11.II.D.11, 01/03/11).

NASSIF, A., FEIJÓ, C. and ARAÚJO, E. (2012). "The long-term "optimal” real exchange rate and the currency overvaluation trend in open emerging economies: The case of Brazil". UNCTAD Discussion Papers. Geneva: United Nations Conference on Trade and Development, forthcoming.

OCAMPO, J. A. (2011). "Balance of payments dominance: Its implications for macroeconomic policy". School of International and Public Affairs. Columbia University. Unpublished paper.

OREIRO, J. L., PASSOS, M., LEMOS, B. and PADILHA, R. (2009). "Metas de inflação, independência do Banco Central e a governança da política monetária no Brasil: Análise e proposta de mudança" In: L. F. de Paula and R. Sobreira (org.). Política Monetária, Bancos Centrais e Metas de Inflação: Teoria e Experiência Brasileira. Rio de Janeiro: Ed. FGV.

OSTRY, J., GHOSH, A., HABERMEIER, K., CHAMON, M., QURESHI, M., and REINHARDT, D. (2010). "Capital inflows: the role of controls". IMF Staff Position Note, SPN/10/04. Washington, DC.: International Monetary Fund, February 19, 2010.

PASTORE, A. F. and PINOTTI, M. C. (2011). "O câmbio no Brasil: Perguntas e respostas”. In: J. P. R. Velloso (coord.). China, Índia e Brasil: O País na Competição do Século. Rio de Janeiro: José Olympio Editora.

PRASAD, E., RAJAN, R. and SUBRAMANIAM, A. (2006). "Foreign capital and economic growth". Washington: IMF Research Department.

RAZIN, O. and COLLINS, S. M. (1999). "Real exchange rate misalignments and growth". In: Razin, A. and Sadka, E. (eds.). The Economics of Globalization: Policy Perspectives from Public Economics. Cambridge: Cambridge University Press.

RODRIK, D. (2008). “The real exchange rate and economic growth". Brookings Papers on Economic Activity, 2:365-412.

ROMER, D. (2001). Advanced Macroeconomics. Second Edition. Boston: McGraw Hill.

SARGENT, T.J. and WALLACE, N. (1981). "Some unpleasant monetarist arithmetic", Federal Reserve Bank of Minneapolis Quarterly Review, 1-17.

SQUEFF, G. C., OREIRO, J. L. and PAULA, L. F. (2009). "Flexibilização do regime de metas de inflação em países emergentes: uma abordagem Pós-Keynesiana” In: Luiz F. de Paula and Rogério Sobreira (org.) (2009). Política Monetária, Bancos Centrais e Metas de Inflação: Teoria e Experiência Brasileira. Rio de Janeiro: Ed. FGV.

STIGLITZ, J. (2002). Globalization and its discontents. New York: W.W. Norton.

VEJA (2010). "O guardião da estabilidade fica”. April 4 (available at http://www.veja.abril.com.br).

THE WALL STREET JOURNAL (2010). "How it works; when it doesn't”. November 4, 2010.

WILLIAMSON, J. (2008). “Exchange Rate Economics”. Working Paper Series WP 08-3. Washington, D.C., Peterson Institute for International Economics.

WOODFORD, M. (2003). Interest and Prices. Princeton: Princeton University Press, Princeton. 